\title{
Rationality of Reincorporating the Reserved Seat Provision in the Constitution of The People's Republic of Bangladesh
}

\author{
Tasmiah Nuhiya Ahmed \\ Bangladesh Supreme Court, Dhaka, Bangladesh
}

\begin{abstract}
The Constitution (17th Amendment) Act 2018, passed on this 8th July 2018, provides for the tenure of the reserved seats for women in Parliament to be extended for a period of 25 years from the first day of the 11th parliament. In Bangladesh, there is a consensus in general that women's political participation is necessary for both the democratic development of the country and women's empowerment. Studies and research on the constitutionality of the Reserved Seat Provision for women in Parliament show that this Reserved Seat Provision does not actually help women impact in the political process in Parliament and/or in achieving the goals of women empowerment. Hence, this paper shall discuss how this Reserved Seat Provision is affecting the election system, leaving a scope for it to be less democratic, effective, and meaningful. This paper shall highlight that merely a sizable presence of women in Parliament for such a long period won't aid in achieving the aims and objectives of women empowerment. This paper shall conclude with the recommendation that the Reserved Seat Provision may be integrated in the Constitution in a manner that provides for direct election of reserved seat nominations for women in Parliament and that too should not be in the Constitution for an indefinite period.
\end{abstract}

Keywords: reserved seat, women empowerment, Parliament, Constitution, Constitutional Amendment, Bangladesh

\section{Introduction}

In Bangladesh, there is broad consensus that women's political participation is necessary for both the democratic development of the country as well as women's empowerment (IFES, 2016, para. 1). The provisions of reserved seats for women were incorporated in the Original Constitution ${ }^{1}$. The purpose was to secure a minimum representation of women in Parliament and to ensure a wider participation by them in national politics (Ahmed, 2018). However, based on my research, it can be stated that these Reserved Seat Provisions do not help women impact on the political process through increasing their effectiveness in parliament.

The Constitution (17th Amendment) Act 2018, passed on 8th July 2018, provides for the tenure of the reserved seats for women in Parliament to be extended for a period of 25 years from the first day of the next parliament (11th Parliament) (Hereinafter to be referred as "Reserved Seat Provision").

Tasmiah Nuhiya Ahmed, Advocate of Bangladesh Supreme Court and Researcher of Law at Bangladesh Institute of Law and International Affairs (BILIA), Dhaka, Bangladesh.

1 Article 65(3) of the Original Constitution of Bangladesh 1972 provides that: Until the dissolution of parliament occurring next after the expiration of the period of ten years beginning from the commencement of this Constitution, there shall be reserved fifteen seats exclusively for women members, who shall be elected according to law by the members aforesaid: Provided that nothing in this clause shall prevent a women from being elected to any of the seats provided for in clause (2). 
Therefore, the tenure of reserved seats for women in Parliament is extended for a period of 25 years from the date of the first meeting of the 11th Parliament in Bangladesh in the year 2019.

The Constitution (17th Amendment) Act 2018 is against the spirit of the Constitution though not unconstitutional and it would cripple the growth of women's political empowerment. The Original Constitution in 1972 also included this provision of reserved seats for women in parliament despite that it received criticisms from some constituent assembly members who thought that this provision amounts to a lack of faith in the principle of equal rights of men and women in every sphere of life; it rather makes the women dependent on the other section (Halim, 2010, p. 120). Hence, it is my opinion that it should be reinstated in the Constitution in a manner that provides for direct election of reserved seat nominations.

Whatever the noble reason, cause, or philosophy it might have been, those who framed the said law did not apply their cautious mind to make the selection system democratic, effective, and meaningful. It is high time to realize that merely a sizable presence of women in parliament won't suffice. The new recruits from reserved seats shall have to act as the agency for change. They need to come out from ending up internalizing the prevalent rules of politics;

The Draft of the Original Constitution of the 1972 does not contain a provision on reserved seat for women in Parliament (Halim, 2010, p. 82). Under Article 66, it only states that Parliament shall consist of 300 members to be elected in accordance with law form [sic.] single territorial constituencies by direct election (Halim, 2010, p. 82). Thereafter, it might have been included as some arguments can be found in the debate of the members of the Constituent Assembly of Bangladesh on this issue and also in the Report of the Constitution Drafting Committee. In the Report of the Constitution Drafting Committee, it was mentioned that Mr. Suranjit Sen Gupta M. C. A. expressed his concern that this provision amounts to a lack of faith in the principle of equal rights of men and women in every sphere of life as recognized in the Constitution. He carried on stating that the provision for reserved seats for women does not ensure equal rights for men and women in every sphere of life; it rather makes the women dependent on the other section. And thereafter he suggested that the words "there shall be fifteen seats reserved for women members" be deleted, and Constitutional recognition be given by providing that women are equal to men in every sphere of life (Halim, 2010, p. 120).

As such, this paper shall discuss the basis of considering the proposed amendment as unconstitutional and the courts' response in this regard. It shall end up suggesting few arguments that were missing in the petitions, challenging the law on Reserved Seat Provisions before and could have been put forward before the courts by the lawyers who represented the petitioners while challenging the constitutionality of the Reserved Seat Provisions.

\section{History}

Bangladesh first introduced a quota for women in the 1972 Constitution for a period of 10 years, with 15 seats reserved for women in addition to the 300 general seats (Government of Bangladesh, 1972). In 1979, a constitutional amendment increased the number of women's reserved seats to 30 for a total period of 15 years. This amendment expired in 1987, and as a result, there were no reserved seats in the subsequent election (Government of Bangladesh, 1972). The 10th Amendment to the Constitution in 1990 included a new provision of 30 seats for 10 years, which ended in 2000 (IFES, 2016, para. 3). In the Eighth Parliament Elected in 2001 there was no quota for women, but it passed the 14th Amendment to the Constitution, which guaranteed 45 seats for women for a period of 10 years (IFES, 2016, para. 3). To give effect to Article 65(3) of the 
Constitution, Parliament, on 29th November 2004, enacted the Jatiya Sangsad (Reserved Seats for Women) Election Act 2004 for holding indirect election by the 300 directly elected Members of Parliament (MPs). This was increased to 50 seats with the 15th Amendment in 2011. The period of 10 years expires prior to the next scheduled general election in 2019. Recently in 2017, the Law Ministry proposed to extend the tenure of women MPs (reserved seat) in parliament by 20 years. The Cabinet Division on January 29, 2018 approved in principle the draft of the 17th Amendment to the Constitution with the provision which provides for the extension of the tenure of women MPs (reserved seat) by another 25 years. This has been decided as the tenure of women MPs (reserved seat) in the Parliament will end on January 24, 2019. It is worth noting that there was a concerted effort to reform the parliamentary reserved seats system in 2008. The caretaker government in power at the time had proposed a 33 percent quota for women in Parliament via a direct election and a separate quota for cabinet members. However, due to strong and vocal opposition by senior Islamic scholars and clerics, the proposal was abandoned (Mantoo, 2014).

\section{How the System Works in Bangladesh?}

Bangladesh has a "first-past-the-post" (FPTP) system $^{2}$ for general seats in Parliament, and a single transferable vote (STV) system for women's reserved seats based on the number of seats secured by a political party. The reservation for women Members of Parliament (MPs) at the national level is 50 seats out of a total of 350 seats (IFES, 2016, p. 5).

\section{Cases in Which the Reserved Seat Provisions Have Been Challenged Before Courts}

The constitutionality of the Reserved Seat Provisions in law has been challenged several times before the courts including in the following cases:

(a) Farida Akhter and Others Vs Bangladesh and Others 11 (2006) MLR (AD) 233,

(b) Dr. Ahmed Hussain V Bangladesh 44 DLR (AD) 109.

However, in both the cases the petitioners have failed to establish their claims before the courts.

\section{Arguments Put Before the Courts by the Petitioners Challenging Reserved Seat Provision}

Violation of the Fundamental Principle of State Policy-The reserved seat provision is contrary to the Fundamental Principle of State Policy ${ }^{3}$ (Article 10, 11, \& 19 of the Constitution). In interpreting the said provision of Article 65(3) read with Act 30 of 2004 as to whether the same are repugnant to Article 7(2) of the Constitution which stand for democratic character of the Republic, the basic structure of the Constitution, the Constitution is the solemn expression of the will of the people, the supreme law of the Republic and if any

\footnotetext{
${ }^{2}$ First-past-the-post (FPTP) is a plurality-majority electoral system. In FPTP, the winning candidate is the person who wins most votes in a single-member district. STV is a proportional system; in proportional systems, seats are allocated in proportion to the votes secured by each party. For more information about plurality-majority and proportional systems, refer to ACE Project on Electoral Systems.

${ }^{3}$ Our Fundamental Principle of State Policy enshrines that the State shall encourage local Government institutions composed of representatives of the areas concerned and in such institutions special representation shall be given, as far as possible, to peasants, workers, and women and in Article 11, the Republic shall be democracy in which fundamental human rights and freedoms and respect for the dignity and worth of the human person shall be guaranteed and in which effective participation by the people through their elected representatives in administration at all levels shall be ensured. In interpreting those Articles 9 and 11 which according to the Constitution itself work as guide to the interpretation of the Constitution and the laws of Bangladesh and inconformity with the principles and legal provisions made to further the cause of State Policy must prima facie be constitutional and apparently clear and must not appear to be ambiguous and found to be inconsistent with any provision of Part-II because of these principles of State Policy having been treated as fundamental to the governance of Bangladesh.
} 
other law is inconsistent with the Constitution that other law shall to the extent of the inconsistency be void. A law is inconsistent with other if they cannot stand together while governing the self same subject-matter. The said Article is fundamental to the governance of Bangladesh, shall be applied in the making of laws and designed as a guide to the interpretation of the Constitution, of other laws, and shall form the basis of the work of the State and of its citizen (Farida Akhter and Others Vs Bangladesh and Others 11 (2006) MLR (AD) 233 para. 47);

Violation of the right to equality before law-The petitioners are not being treated in accordance with law inasmuch as it has not given them the opportunity of participating in the reserved seats as they are not members of any political party, has curtailed the power of the people, and has authorized the political parties, especially the party in power, to nominate Members of Parliament by themselves (Farida Akhter and Others Vs Bangladesh and Others 11 (2006) MLR (AD) 233 para. 4);

Violation of the right to protection of law-The impugned amendment has disregarded and disrespected the said fundamental rights enshrined in Article 31 of the petitioners so far as it has provided that the reserved seats will be filled in by the existing Members of the Parliament by a single transferable vote. Hence the Act is ultra vires and it has been passed without any lawful authority and of no legal effect (Farida Akhter and Others Vs Bangladesh and Others 11 (2006) MLR (AD) 233 para. 4);

Violation of the right to freedom of movement, freedom of assembly, freedom of association, freedom of thought and conscience and speech, and freedom of profession and occupation-In this process, the party in power nominates only those women who are the members and leaders of their own political party contrary to Articles 36, 37, 38, 39, and 40 of the Constitution guaranteeing freedom of movement, freedom of assembly, freedom of association, freedom of thought and conscience and speech, and freedom of profession and occupation. The right to join or not to join a political party is the fundamental right of the women but the amendment is designed forcing the women to join as such contrary to their will in order to be a member of the Parliament (Farida Akhter and Others Vs Bangladesh and Others 11 (2006) MLR (AD) 233 para. 4);

Prejudicial to all the fundamental rights-All the petitioners have the requisite positive constitutional and legal qualifications to be a Member of Parliament holding the said qualifications provided in Article 66 of the Constitution read with section 8 of the Act but could not be a member of Parliament in the reserved seats only because they are not members of any particular political party seriously prejudicing their fundamental rights (Farida Akhter and Others Vs Bangladesh and Others 11 (2006) MLR (AD) 233 para. 4);

Contrary to the basic feature of the Constitution-The impugned amendment is absolutely in contravention of the basic feature of the Constitution inasmuch as it does not reflect or contain the direct participation of the people and hence it is liable to be declared to have been passed without any lawful authority and of no legal effect (Farida Akhter and Others Vs Bangladesh and Others 11 (2006) MLR (AD) 233);

An arbitrary and capricious system-After the dissolution of the current Parliament to be elected on the basis of procedure of proportional representation in the Parliament through single transferable vote, which is not just workable but arbitrary, capricious, and contrary to the basic structure of the Constitution (Farida Akhter and Others Vs Bangladesh and Others 11 (2006) MLR (AD) 233 para. 5);

Discriminating between general seat and reserved seat members-This shall cause discrimination amongst smaller political parties or independent MPs inasmuch as they will not have a representation through a woman MP. Thus, there will be discrimination in the House of Nation amongst MPs from the general seat when they will indirectly elect 45 women MPs for reserved seats, which is incongruent with Article 27 of the Constitution 
(Farida Akhter and Others Vs Bangladesh and Others 11 (2006) MLR (AD) 233 para. 5);

Mandatorily requiring to join a political party-A woman who is otherwise eligible to become MP, but who does not belong to any political party, is debarred from becoming an MP for the reserved seat under the impugned amendment. Because in order to be nominated she must belong to a political party or a group in Parliament which commands at least 6.67 parliamentary seats (Farida Akhter and Others Vs Bangladesh and Others 11 (2006) MLR (AD) 233 para. 5);

Discrimination amongst small political parties-Under this system, every political party or a group of MPs who commands 6.67 seats shall proportionately be entitled to one woman MP from the reserved seats, which shall cause discrimination amongst smaller political parties having less than 6.67 seats or independent MPs inasmuch as they will not have a representation through a woman MP (Farida Akhter and Others Vs Bangladesh and Others 11 (2006) MLR (AD) 233 para. 5);

Ultra vires to the Constitution and void ab initio and a nullity-

(a) The 4th schedule is limited within the transitory period between 26th March 1971 and until the operation and commencement of the Constitution in 1972, in order to give cover to such interim and temporary laws, which came into operation prior to the commencement of the Constitution. Thus the scope and ambit of the 4th Schedule has already been exhausted through the passage and expiry of the transitory period as contemplated by the framers of the Constitution,

(b) It is absurd to have a temporary special provision (4th Schedule) arising out of a temporary special provision i.e. Article 65(3), which is itself temporary,

(c) The 4th Schedule in any event has always been used to insert temporary laws not Articles of the Constitution itself. The 4th Schedule is not capable of absorbing temporary Articles of the Constitution itself,

(d) Insertion of the residual period of this Parliament in the 4th Schedule is inappropriate, since its proper place is within the main body of Constitution itself,

(e) Insertion of the residual period of this Parliament in the 4th Schedule is therefore inappropriate, since its proper place is within the main body of Constitution itself,

(f) That the impugned paragraph 23(2) in the 4th Schedule has by operation law created a Parliament, consisting of 345 members, effective from the operative date of the 14th Amendment of the Constitution (i.e., 17th May 2004), which is another absurdity. Because without first passing of any law by the present Parliament to indirectly elect 45 women MPs, it cannot change its own constitution from 300 MPs to 345 MPs. Therefore such an inoperative and absurd provision is void ab initio (Farida Akhter and Others Vs Bangladesh and Others 11 (2006) MLR (AD) 233);

Encourages nepotism and surrogate male nomination of candidates - In a systemic way this method ensures that these women always remain subservient to the majority male MPs purely on the ground of gender. It encourages nepotism and surrogate male nomination of candidates to these reserved seats in the sense that if the husband or other male party members is refused nomination from a general seat, then as a consolation, his wife or some other close female relation or a relative of a party loyalist is offered the reserved seat, etc. Very rarely women who are capable on their own merit are offered these seats, which inevitably go to those who enjoy a close relationship with a party loyalist or a party boss. Therefore, this system discourages true political empowerment or leadership amongst women which is tantamount to degrading treatment towards them (Farida Akhter and Others Vs Bangladesh and Others 11 (2006) MLR (AD) 233 para. 5);

Reserved and general seat members are unequal- 
(a) Being elected in the reserved seat the commissioners cannot claim to be equal with the commissioners elected in the general seat and reasonable classification is permissible but the petitioners cannot be treated at per with them simply because they are unequal (Shamima Sultana \& Ors V Bangladesh \& Ors 14 (2006) BLT (HCD) 33, para. 15),

(b) Women commissioners who were elected in the reserved seat are a class by themselves and obviously cannot be equated with the Commissioners elected in the general seats and being so unequal cannot claim equal treatment and equal rights vis-à-vis the Commissioners elected in the general seats (Shamima Sultana \& Ors Vs Bangladesh \& Ors 14 (2006) BLT (HCD) 33, para. 15) — made by the respondent);

Secondary Position of Inferior Status-Reserved seat members hold secondary position of inferior status (Shamima Sultana \& Ors Vs Bangladesh \& Ors 14 (2006) BLT (HCD) 33, para. 15) - made by the respondent);

Violates the inbuilt doctrine of equal justice, political, social, and economic - The amendment has violated the inbuilt doctrine provided in the preamble to our Constitution that there should be equal justice, political, social, and economic, secured to all citizens connoting the concept to be the fundamental structure of the Constitution inasmuch as the women of the Country are not entitled to vote, to have the same value in terms of their respective representation and the same could not be diluted by introducing the unequal concept as the amendment has done away with the concept that the election should be open to all (Farida Akhter and Others Vs Bangladesh and Others 11 (2006) MLR (AD) 233, para. 22);

Cripples the growth of women's political empowerment (Farida Akhter and Others Vs Bangladesh and Others 11 (2006) MLR (AD) 233, para. 5) -

(a) It does not encourage the growth of women's leadership or political empowerment of women, which can only happen by way of direct election. Instead false, incorrect, and sometimes demeaning loyalties and alliances are encouraged with a culture of subservience which is tantamount to "degrading treatment" towards women and as such it is crippling the political growth and empowerment of women, as a class, at the expense of a few individuals who are encouraged in a systemic way to serve the patriarchy in a submissive manner at the whims and caprices of the male leaders (Farida Akhter and Others Vs Bangladesh and Others 11 (2006) MLR (AD) 233),

(b) Since the seats of these women depend upon the choice of the male majority, these women can hardly ever rise as leaders over and above their male counterparts, and therefore in a systemic manner it cripples the growth of political empowerment of women, emerging as a class or a critical mass to be reckoned on their own merit, not at the mercy or account of other politicians, but directly accountable to the people;

Vague, complicated, illogical, inconclusive, incomprehensive, and impossible to be understood and followed-It discriminates against a lady citizen who does not belong to a political party or a jote as she would not get any chance to contest the 45 reserved seats. Hence, the law should be struck down as being vague, complicated, illogical, inconclusive, incomprehensive, and impossible to be understood and followed by an ordinary citizen especially the quota system in sections 16, 28, and third schedule (Farida Akhter and Others Vs Bangladesh and Others 11 (2006) MLR (AD) 233, para. 6);

Violation of the Articles on Elections (Dr. Ahmed Hussain V Bangladesh 44 DLR (AD) 109, para. 4)-

(a) The reserved seat system violates the rule of single electoral roll for each constituency which provides that there shall be one electoral roll for each constituency for the purposes of elections to Parliament, and no special electoral roll shall be prepared so as to classify electors according to religion, race, caste, or sex (Article 
121),

(b) It does not meet the requirement of qualifications for registration as voter which requires the elections to Parliament to be on the basis of adult franchise (Article 122 (1)) (Adult franchise is a fundamental pillar of any democracy. Adult franchise means that the right to vote should be given to all adult citizens without the discrimination of caste, class, colour, religion, or sex. It is based on equality which is a basic principle of democracy) (Dr. Ahmed Hussain V Bangladesh 44 DLR (AD) 109, para. 4);

Destroying the principle of democracy (Dr. Ahmed Hussain V Bangladesh 44 DLR (AD) 109, para. 4) -

(i) The impugned amendment, by providing for indirect election for the seats reserved exclusively for women, has destroyed the principle of democracy as -

(a) The high ideals of nationalism, socialism, democracy, and secularism, which inspired our heroic people to dedicate themselves to, and our brave martyrs to sacrifice their lives in, the national liberation struggle, shall be the fundamental principles of the Constitution (Preamble),

(b) Clause (1) of Article 7 provides that all powers in the Republic belong to the people, and their exercise on behalf of the people shall be effected only under, and by the authority of, this Constitution,

(c) Article 8 provides that the principles of nationalism, socialism, democracy, and secularism, together shall constitute the fundamental principles of state policy,

(d) Article 11 provides that the Republic shall be a democracy in which fundamental human rights and freedoms and respect for the dignity and worth of the human person shall be guaranteed and in which effective participation by the people through their elected representatives in administration at all levels shall be ensured (Dr. Ahmed Hussain V Bangladesh 44 DLR (AD) 109, para. 4);

(ii) The scheme of our Constitution providing for Parliamentary democracy making a member of parliament responsible to the electorate/people electing him buy [sic.] the alleged election to the reserve seats without any constituency makes the election meaningless cutting at the root of the parliamentary democracy inasmuch as the scheme of instant election differentiate between one woman and another as woman other than nominee of political party has no chance to be elected as a member of Parliament in the changed process to the election, thereby making some women more equal than the others (Farida Akhter and Others Vs Bangladesh and Others 11 (2006) MLR (AD) 233, para. 21);

Destroyed the concept of constituency-

Each vote should be given due weight instead of weightage of vote diluting creating inequality resulting in violation of political justice alleging that the Act of 2004 has destroyed the concept that constituency is the part of distributive justice and the build in concept of equality has been mutilated, which promotes equal votes of equal value and the concept of equal right (a book titled Limitations on Government Power by Nowak, Rotunda, and Young);

The impugned amendment is inconsistent or repugnant to Article 119(1)(c) of the Constitution. As we have already pointed out that Article 65(2) provides for two types of member of Parliament in the House of Nation, i.e., one 300 members to be elected in accordance with law from single territorial constituencies by direct election and Article 119(1)(c) speaks of delimitation of these constituencies for the purpose of election to the Parliament, i.e., for 300 general seats as mentioned in Article 65(2) (Farida Akhter and Others Vs Bangladesh and Others 11 (2006) MLR (AD) 233, para. 54).

\section{Courts' Response to the Claims of the Writ Petitioners}


The court expressed its observations in the following terms:

Does not destroy the basic character/structure of the Constitution-The court observed that the founding fathers of the Constitution contemplated two types of members of Parliament, one 300 members of Parliament to be elected in accordance with the law from single territorial constituencies by direct election and certain number of members in the reserved seats exclusively for women members who shall be elected according to law by the members aforesaid. The present amendment after the expiry of previous Act 10th Amendment Act of 1990 has substituted the present one whereby 45 seats exclusively for women members shall be elected in accordance with law on the basis of proportionate representation in the Parliament through single transferable vote for a period of 10 years beginning from the date of the meeting of the next Parliament. Thus the said provision was in the Constitution in some form or other since commencement of the Constitution and it does not lie in the month of the writ petitioners that the substitution of 45 seats of the previous provision has destroyed the basic character/structure of the Constitution (Dr. Ahmed Hossain vs. Bangladesh and others 44 DLR (AD) 109);

Not unconstitutional-The substitution of earlier clause (3) of Article 65 or the Constitution by the new one cannot be challenged ultra vires the Constitution for the simple reason that the said provision was there in the Constitution since its commencement (Dr. Ahmed Hossain vs. Bangladesh and others 44 DLR (AD) 109);

Reflection of what the framers of Constitution visualized-The framers of the Constitution visualized and contemplated certain seats reserved exclusively for women members who shall be elected according to law by the members of Parliament. They shall be elected according to law by the members of Parliament (Farida Akhter and Others Vs Bangladesh and Others 11 (2006) MLR (AD) 233);

No violation of principle of equality before law or protection of an equal law-The challenge to the law on the ground of offending principle of equality before law or protection of an equal law for holding the amendment to be ultra vires the provisions of Article 27 and 38(3) of the Constitution falls to the ground for the simple reason that the said phrases are not to be interpreted in the absolute sense to be held all person are equal in all respect disregarding different condition and circumstances in which they are placed or special qualities and characteristics which some of them may possess but which are lacking in others (Farida Akhter and Others Vs Bangladesh and Others 11 (2006) MLR (AD) 233);

Constitution demands for Reserved Seat Provision-In view of the socio-economic background of our society as the women are lagging behind in all spheres of national life including administration at all levels for good reasons, our Constitution postulates in Article 10 that steps shall be taken to ensure participation of women in all sphere of national life and in Article 11 thereof that the democratic Republic shall guarantee the fundamental human rights and freedoms and shall have respect for the dignity and worth of the human person in which effective participation by the people through their elected representatives in administration at all levels shall be ensured. It is also the determined aim of the State to promote local Government institutions by encouragement and participation of women through special representations as far as practicable (Article 9), for there was no classification between people's representation in the local Govt. bodies and those in the Parliament and they are treated as one and similar class (Farida Akhter and Others Vs Bangladesh and Others 11 (2006) MLR (AD) 233);

Uphold the principles of Democracy-

(a) No violation of the interpreting the said provision of Article 65(3) read with Act 30 of 2004 as to whether the same are repugnant to Article 7(2) of the Constitution which stand for democratic character of the 
Republic, the basic structure of the Constitution, the Constitution is the solemn expression of the will of the people, the Supreme law of the Republic, and if any other law is inconsistent with the Constitution that other law shall to the extent of the inconsistency be void. A law is inconsistent with other if they cannot stand together while governing the self same subject-matter. The said Article is fundamental to the governance of Bangladesh, shall be applied in the making of laws and designed as a guide to the interpretation of the Constitution, of other laws, and shall form the basis of the work of the State and of its citizen (Farida Akhter and Others Vs Bangladesh and Others 11 (2006) MLR (AD) 233),

(b) A system of indirect election cannot be called undemocratic. It is provided in the Constitution itself (Dr. Ahmed Hussain V Bangladesh 44 DLR (AD) 109);

Does not destroy the concept of Constituency-The election to the reserved seats, a separate provision has been made therein by connoting such members as designated members of Parliament for so long which is a special procedure provided by law and has nothing to do with constituency or its delimitation. Previously P. O. No. 17 of 1973 and presently Act 30 of 2004 provide for modalities of conducting the election for 45 reserved seats exclusively for women members in the Parliament who shall be designated as Members in Parliament under Article 65(2) and Article 119(1)(c) is for the election of 300 members elected on the basis of single territorial constituencies who shall form a electoral roll or electoral college for the purpose of electing women members to the reserved seats (Farida Akhter and Others Vs Bangladesh and Others 11 (2006) MLR (AD) 233);

Does not destroy the rule of election-

(a) Article 121 of the Constitution provides for single electoral roll for each constituency so far the election to 300 members of Parliament to be elected in accordance with law from single electoral constituency by direct election and Article 122(1) thereof provides for election to Parliament shall be for the 300 members to be elected in accordance with law from single territorial constituency by direct election on the basis of adult franchaise wherein a person with requisite qualification provided therein shall be entitled to be enrolled on the electoral roll for a constituency delimited for the purpose of election to the Parliament (Farida Akhter and Others Vs Bangladesh and Others 11 (2006) MLR (AD) 233),

(b) The Constitution on the date of its commencement provided for two different kinds of elections. Three hindered members of the Parliament are to be elected in accordance with law from single territorial constituency by direct election. Members for seats reserved exclusively for women are to be elected by the members of the Parliament, according to law. The Representation of the People (Seats for Women Members) Order 1973 (P. O. No. 17 of 1973) provides for that law. We find no conflict between the impugned amendment and Articles 121 and 122(1) of the Constitution (Dr. Ahmed Hussain V Bangladesh 44 DLR (AD) 109);

Not repugnant to the Constitution-Since commencement of the Constitution, Article 65(3) was there who shall only be designated as member of Parliament as provided in Article 65(2) and so long as clause (3) is effective the members provided for in that clause shall be the members of Parliament and provision has been made for reserved seats exclusively for women to be elected in accordance with law made by the Parliament and such members shall be designated as members of parliament and subsequently the previous Article 65(3) has been substituted by a similar provision enhancing the number of reserved seats to 45 by the 14th Constitutional Amendment Act 2004; the same cannot be said to be violative or inconsistent or repugnant to the Constitution (Farida Akhter and Others Vs Bangladesh and Others 11 (2006) MLR (AD) 233); 
Does not offend the doctrine of basic structure of the Constitution-With reference to the 8th Amendment case judgment by this court in Anwar Hossain Chowdhury vs. Government of Bangladesh and Ors reported in 41 DLR (AD) 1675, the court concluded that the amendment has not offended the doctrine of basic structure of the Constitution (Farida Akhter and Others Vs Bangladesh and Others 11 (2006) MLR (AD) 233);

Not undemocratic - A system of indirect election cannot be called undemocratic. It is provided in the Constitution itself. The amendment is not also violative of Article 28. Clause (4) in Article 28 provides that nothing in that Article shall prevent the State, which expression includes Parliament, from making special provision in favour of women (Dr. Ahmed Hossain vs. Bangladesh reported in 44 DLR (AD) 109);

A measure of stopgap arrangement to provide for continuity of women reserved seat in the present parliament-Article 150 of the Constitution empowers the Parliament to provide for any transitional and temporary period or purpose as the heading connotes. Since we have held that amended provision of Article 65(3) of the Constitution substituting the earlier provision thereof to have been made lawfully which is to take effect from the first meeting of the Parliament next after the Parliament of existence at the time of the commencement of the Constitution (14th Amendment) Act 2004, i.e., the present Parliament, the Parliament in its wisdom did make transitory temporary special provision regarding reserved 45 seats exclusively for women members in the present parliament under the provision of Article 150 of the Constitution as an interim measure providing representation of the women in between the present parliament and the next parliament as a measure of stopgap arrangement to provide for continuity of women reserved seat in the present parliament (Farida Akhter and Others Vs Bangladesh and Others 11 (2006) MLR (AD) 233);

Does not curtail franchise right of the citizen-The said Act, not for a moment does curtail franchise right of the citizen because previously as well barring the members of the parliament, the citizens had no part to play in the election of the reserved seats for women as the founding fathers of the Constitution mandated. The modalities and procedure have been provided in the Act for proportional representation, a universally accepted common mathematical mechanism to determine the proportion among the political parties. Jote or independent members representing the parliament, adopted by other Countries where the election is held on the basis of procedure of proportional representation (Farida Akhter and Others Vs Bangladesh and Others 11 (2006) MLR (AD) 233);

Similar with Pakistan Constitution-Similar provision was envisaged in the Constitution of the People's Republic of Pakistan 1973 in its "Article 51" (Farida Akhter and Others Vs Bangladesh and Others 11 (2006) MLR (AD) 233);

Reflect the purpose and procedure and for materializing the object of the amended provision of the Constitution - It is designed to reflect the purpose and procedure and for materializing the object of the amended provision of the Constitution providing for election to the 45 reserved seats for the women in the Parliament on the basis of 34 procedure of proportional representation in the parliament through single transferable vote enhancing the cause of democracy through a process which could not be termed as undemocratic (Farida Akhter and Others Vs Bangladesh and Others 11 (2006) MLR (AD) 233);

Cannot be challenged ultra vires-In the original Constitution, passed by the Constituent Assembly, there was a similar provision for reservation of 15 seats for women for 10 years in addition to 300 seats for members of Parliament. By Second Proclamation Order No. IV of 1978, the number of seats was increased to 30 seats and the period was extended to 15 years from the date of the commencement of the Constitution. That period expired on 16 December, 1987. By the impugned Act, the period for reservation of 30 seats for women 
members was further extended. The petitioner contends that after the period for reservation of 30 seats expired on 16th December, 1987, no extension could be made. We do not find any substance in this contention. Clause (3) of Article 65 was never deleted. It remained in the Constitution. The substitution of the earlier clause (3) by the new one cannot be challenged as ultra vires (Dr. Ahmed Hussain V Bangladesh 44 DLR (AD) 109);

Is not discriminatory-The amendment is not also violative of Article 28. Clause (4) in Article 28 provides that nothing in that article shall prevent the State, which expression includes Parliament, from making special provision in favour of women. We find no merit in this petition and, accordingly, it is dismissed (Dr. Ahmed Hussain V Bangladesh 44 DLR (AD) 109);

\section{Arguments That Were Not Placed But Could Have Been While Challenging the Reserved Seat Provisions}

Quotas are a double-edged sword - On the one hand, the Reserved Seat Provisions oblige men to think about including women in decision-making, since men must create spaces for women. On the other hand, since it is men who are opening up these spaces, they will seek out women who they will be able to control—women who will more easily accept the hegemony of men (Anna Balletbo, former MP, Spain) (Varghese, 2015);

Encourages "winner takes all" nature of politics-Since the reserved seats in Bangladesh are allocated in proportion to the percentage of general seats (as opposed to in proportion to the percentage of votes) won by each party in the parliamentary election in a FPTP system, it results into "winner takes all" nature of politics, which is one of the key drivers of political deadlock in Bangladesh (IFES, 2016, pp. 4-5);

Ensures one party's complete dominance in Parliament-In certain cases, for example, when the party has already a two-third majority, women's reserved seats is being used to ensure one party's complete dominance in Parliament (IFES, 2016, pp. 4-5);

Contributes to tokenism of women representatives-The International Foundation for Electoral Systems (IFES), which supports citizens' right to participate in free and fair elections, produced a report titled, "Women's Reserved Seats in Bangladesh: A Systemic Analysis of Meaningful Representation" for the U.S. Agency for International Development identified that the current reserved seats systems may have contributed to tokenism of women representatives and further marginalization due to, among other factors, overlapping mandates and lack of constituencies for women elected through Temporary Special Measures (TSMs) (IFES, 2016, pp. 4-5);

Contributes to the disproportionality-The current parliamentary reserved seats system contributes to the disproportionality of an already disproportional electoral system, due to the fact that the seats are allocated based on first-past-the-post (FPTP) results. (A first-past-the-post (FPTP) voting method is one in which voters indicate on a ballot the candidate of their choice, and the candidate who receives the most votes wins: This is described as winner takes all. First-past-the-post voting is a plurality voting method) (IFES, 2016, pp. 4-5);

Being in a place of power may not be sufficient on its own to empower and achieve meaningful equality-Numerical representation is a stepping stone towards meaningful representation, which means that it does aim for ensuring women's political empowerment. However, it may not suffice to ensure the true purpose of representation. Moreover, experts also have the concern that gender quotas are an insufficient, but a necessary concept to realise gender equality in society: Despite the drawbacks, having a gender quota is definitely an improvement and brings women closer to true gender equality;

Why Local Government election process system is not being followed?-Local government election 
process system can be followed in parliamentary election process;

Numerical representation does not necessarily translate to influence or empowerment-In a 2013 survey by the Khan Foundation, 65 percent of respondents indicated that it is necessary for women to contest general seats in order to achieve "political empowerment". This is in contrast to the only 25 percent of respondents who indicated that a greater number of reserved seats would achieve the same goal. Also, only 54 percent of respondents were of the opinion that reserved seat members in Parliament have "played some role" in politics. The people that responded in the negative gave the following reasons: "political parties not taking reserved seat holders seriously" (50\%) and "absence of proper allocation of work area" (42\%) (Khondker, 2013);

Non-transparent nomination process-At the national level in Parliament, parties prepare the lists of women candidates for reserved seats before the election in order of priority, so the first woman on the list will be the first one assigned to a reserved seat if her party earns enough general seats. However, the Election Commission of Bangladesh (ECB) or the parties do not widely circulate the lists for reserved seats before or after the election, so some candidates and the general public do not have a clear idea of who is on the list, why they are on the list, and in what order (IFES, 2016, pp. 4-5);

Lack of accountability towards citizen-It is confirmed verbally by a senior officer at the Election Commission of Bangladesh, August, 262015 that the reserved seats in Parliament are not elected and are instead de facto selected. Hence, general seat MPs technically comprise the electorate, and the reserved seats have never actually gone to vote. Women who are put on the party lists for reserved seats do not contest in general elections and do not have citizen constituencies to whom they are accountable (IFES, 2016, pp. 4-5);

Disregard of merit-

(a) there are no criteria by which political parties must abide when nominating women for reserved seats. Party leadership has the sole discretion to decide who should be placed on the list and in what order. The selection process is not necessarily merit-based, resulting in potentially under-qualified and unprepared representatives, which further erode the public's trust in their female representatives (IFES, 2016, pp. 4-5; Khondker, 2013, p. 47),

(b) It sometimes fails to question the content of "merit" itself, passing over the many ways in which such criteria systematically privilege certain groups over others, often in arbitrary ways (Krook, 2006);

Lacks in political credentials and gravitas-The issue is not so much the lack of qualifications in terms of education or professional experience; rather, reserved seat holders often lack political credentials and gravitas (Khondker, 2013);

Lack of geographical and socio-economic balance-Since there are no set criteria for nominating women for reserved seats on the national level, parties can nominate candidates without considering geographical representation. Parties can —and often do-nominate elite women from predominantly urban areas; thus, there are very few female representatives from rural areas and/or diverse socio-economic backgrounds (IFES, 2016, pp. 4-5);

Lacks the power base-The reserved seats representatives lack the power base that comes from winning a popular vote. The women in reserved seats are, as a result, beholden to the party leaders instead. A similar type of alienation from constituents has been observed for female and male MPs in South Africa, where the African National Congress (ANC) allowed their MPs to self-select an area to "represent" in order to counteract this issue. Unfortunately, the systemic challenges of alienation persist (Sibalukhulu, 2012);

Do not have a specific constituency-Unlike general seats, reserved seats in Parliament do not have a 
specific constituency that the members represent. Instead, the entire country becomes one large district. Nominees for reserved seats are selected by political parties based on how many seats a party secures (IFES, 2016, pp. 4-5);

Deprived of the constituency development funds-Women in reserved seats are also not allocated the constituency development funds that their general seat counterparts receive, which further weakens their authority and renders them "second-class" MPs. The amount of constituency funds for members of Parliament increased in July 2015 from BDT 30 million per year to BDT 40 million per year, or BDT 200 million (approximately USD \$2.5 million) during the five-year term of an $\mathrm{MP}^{4}$;

Results in overlapping mandates-In Bangladesh, this has been highlighted by Prof. Badiul Alam Majumdar of SHUJAN that reserved seat system is a separate women only tier, which results in overlapping mandates for reserved and general seat holders: Districts have both a general (almost always male) representative and an additional (female) representative (Majumdar, 2010, p. 446);

Unclear law-The role of reserved seats representatives is not clear in the law; the assumption is that they have the same functions as the general seat holders, but in practice this is rarely the case (Interview with Upazila (Sub-District) Election Officer, Gazipur, June 15, 2015). Voters and other stakeholders may also not fully understand or value the function of the "additional" reserved seat members (IFES, 2016, pp. 4-5);

Tokenism and discrimination-Women in reserved seats are often perceived to be less legitimate than those elected to general seats, and they may face discrimination from their male, and sometimes female colleagues in general seats (IFES, 2016, pp. 4-5);

Less prestigious-Holding a reserved seat is intrinsically less prestigious than being elected by popular vote to a general seat (IFES, 2016, pp. 4-5);

Back benchers-In Parliament, political parties often do not allow reserved seat holders to speak on the floor of the assembly, and their resolutions, questions, and suggestions are often ignored. The public also generally views reserved seat holders as "back benchers" who are not very effective in their roles (Khondker, 2013) - this is reinforced by the seating arrangements in Parliament, where reserved seat members are relegated to the very back of the assembly hall (Khondker, 2013);

Rarely holds ministerial positions-Women from reserved seats also rarely hold ministerial positions. Begum Tarana Halim, the first reserved seat member of the current cabinet, was appointed state minister in the July 2015 cabinet reshuffle. Aside from the Prime Minister, the current cabinet has only one full female minister (out of 33) and three lower-ranked female state and deputy ministers (out of 20) (IFES, 2016, pp. 4-5);

Undue influence-The process is also susceptible to corruption and other undue influence by politically connected family members. Women who have been party workers for a long time are often ignored, and women who have no record of accomplishment with a party, but do have kinship or other relationship ties with party leaders, may be placed at the top of the list. This type of favoritism is demoralizing for both potential candidates and the general public. This type of favoritism is demoralizing for both potential candidates and the general public ${ }^{5}$;

\footnotetext{
${ }^{4}$ Announced by the government's highest policymaking body, the Executive Committee of The National Economic Council (ECNEC). See 2015, July 7. Each MP to get Tk20cr for local infrastructures. Prothom Alo.

5 Civil society organization Sushasoner Jonno Nagorik (SHUJAN) estimates that one-fourth of candidates for women's reserved seats in 2014 were nominated based on nepotism. See 2014, March 18. One Fourth Candidates Nominated by Nepotism, Rising BD.
} 
Destabilizes the status quo and may generate a backlash-As this kind of measure primarily aims at redistribution of power, opportunities, and resources, they have the potential for destabilizing the status quo and may generate a backlash, which could undermine the desired outcome (Nanivadekar, 2006);

Women's voice remains missing-Women elected through reserved seats may not pursue women-friendly policy change and hence some scholars consider that it seeks merely to increase the number of women in political decision making, separate from any obligations to change policy outcomes (Krook, 2006);

Biased recruitment practices-Quota policies in almost all cases have exposed the biases of prior recruitment practices (Krook, 2006);

Does not constitute international best practice for election-Quotas do not constitute international "best practice" for elections (Pires, 2002);

Delegitimizes female politicians-The reserved seats for some women may delegitimize all female politicians as political actors, even those who win political office "on their own" through more traditional processes of candidate recruitment (Krook, 2006);

Alters descriptive and substantive pattern of representation of women in policy change-These measures often do play a crucial role in altering existing patterns of descriptive and substantive representation of women in policy change. Despite their emphasis on numbers, for example, these policies in many countries have led to a shift not only in the political agenda but also in the gender consciousness of female representatives and the political engagement of female constituents (Krook, 2006);

Unclear objective of keeping reserved seat members-There is no consensus regarding what is to be expected from women elected through reserved seats. Some believed that women would purify politics, while others held that it would feminize corruption. Some crucial questions still remain unanswered. Some crucial questions still remain unanswered. What is the objective of quotas: merely a sizable presence of women? Can the new recruits from reserved seats act as the agency for change, or would they end up internalizing the prevalent rules of politics? (Nanivadekar, 2006);

Dignity to be achieved through direct election-

(a) Professor Meghna Guhathakurta, Chairperson, Department of International Relations, Dhaka University, once in a dialogue organized by Centre for Policy Dialogue revealed the findings of a survey conducted by Ain-O-Salish Kendra and the ICS. The fact which emerged from the survey showed that people were attaching more importance to the matter of dignity that was to be gained from the direct election than merely the number of seats to be allocated for women,

(b) Ms Khushi Kabir, Excutive Drector of Nijera Kori, expressed in the same event that those women lawmakers should be directly elected,

(c) Ms Rokeya Khatun, Social \& Gender Advisor, CIDA Canadian High Commission expressed her support for direct elections which, in her opinion, would bring deserving women to Parliament,

(d) Ms Shirin Akhter President Karmajibi Nari Jatio Samajtantrik Dal (JSD) thinks that direct election to the reserved seats was a critically important demand which has been put forward by the women's lobbies;

Enforcement mechanism is essential—Effective quotas also require some kind of enforcement mechanism in order to hold someone accountable for their implementation (Baldez, 2006);

Need more equitable representation of women-Gender equality activists are pressing their demands for more equitable representation of women in Parliament;

Ensure "substantive" or "qualitative" representation-The reality in Bangladesh underscores that more 
meaningful, i.e., "substantive" or "qualitative" representation as opposed to mere numerical representation for women, is a necessary goal;

Political and societal demand-The problems associated with the current method of assigning reserved seats in response to the FPTP system for general seats in Parliament warrants examination not only from a gender equity point of view, but from a broader political and societal perspective as well;

Raising awareness-Raising awareness among both political elites and prospective female candidates on the need to revise existing criteria of candidate selection (Krook, 2006);

Reforming the nomination process for reserved seats-Reserved seats for women in Parliament are currently filled based on lists compiled by party leaders. Other than the general candidacy requirements, there are no defined criteria that political parties must follow when nominating women for reserved seats, which has led to a system based on favoritism, cronyism, and a disregard for individual merit. To address this issue, political parties could develop criteria that the ECB would ensure followed. The criteria should be drafted in consultation with stakeholders and include requirements to mandate the nomination of women from all geographic areas to ensure representation of women from various segments of society;

Increase transparency-To increase transparency in the nomination processes for both general and reserved seats at all levels would help to ensure merit-based selection of candidates;

Super-districts for women's seats-The reserved seats at the national level could be filled by creating separate "super-districts" for women only using FPTP, instead of filling the existing reserved seats using lists created by the political parties. The idea is to essentially replicate the system that is already in place for local government elections to the Union, Municipality, and City Councils. The number of super-districts would be the same as the number of reserved seats (currently 50), and each super-district would consist of multiple districts (assuming the current quota size), specifically six general districts for each super-district. This would allow for better geographical ties for women representatives, while also ensuring that the reserved seats are elected positions instead of individuals selected by party leaders. Implementation of this model in Kenya has demonstrated that these women only elections in super-districts can be fiercely competitive under the right circumstances (Daily Nation, 2012);

Alternate threshold system-In the alternate threshold (sometimes called "best loser") system, the reservation would be allocated to women contesting elections for general seats (see "Alternate Thresholds in Jordan" [page 27] for an example). The benefit of this approach is that from a voter's perspective, there is only one election for both men and women and no additional ballots or lists are required;

Combined system or proportional representation - Civil society, academia, and some political parties in Bangladesh have discussed the possibility of changing the entire electoral system to either a combined system or proportional representation, sometimes specifically due to concerns about gender equality in elected representation (Democracy Watch, 2009).

\section{Conclusions}

An increasing number of countries are now repealing this kind of measures on the grounds that they are unconstitutional. The author would rather prefer to term the Reserved Provisions as against the spirit of Constitution instead of unconstitutional. In most cases, courts justify these decisions by referring to existing principles of equality and representation, revealing the deep normative institutional barriers to "gendering" existing criteria of candidate selection. Women's meaningful representation in Bangladesh continues to lag 
behind that of men, due to deeply ingrained cultural, socio-economic, and religious reasons. In addition to these issues, which are present to varying degrees in almost every country in the world, there are unique challenges associated with the way the vast majority of women are elected into office in Bangladesh. The reserved seats systems require reform in order to address key issues that systematically undermine women's effective political leadership. Hence, we seek for the kind attention of the relevant groups of our society to scrutinize these Reserved Seat Provisions one more time taking into account the above mentioned factors.

\section{References}

Ahmed, T. N. (27 April 2018). The constitution and women empowerment. The Independent (Dhaka). Retrieved from $\mathrm{http}: / / \mathrm{m}$. theindependentbd.com/printversion/details/147481 (accessed 19 July 2018)

Baldez, L. (2006). The pros and cons of gender quota laws: What happens when you kick men out and let women in? Politics \& Gender, 2(1), 102-109. doi:10.1017/S1743923X06221019

Daily Nation. (November 4, 2012). Why record number of women aspirants has not rattled men. Retrieved from https://www.nation.co.ke/news/politics/Record-number-of-women-aspirants/1064-1611122-13ptch9z/index.html

Government of Bangladesh. (1972). The Constitution of the People's Republic of Bangladesh (and subsequent amendments). Retrieved from http://bdlaws.minlaw.gov.bd/pdf_part.php?id=367

Halim, M. A. (2010a). Making the Constitution of Bangladesh. In Report of the Constitution Drafting Committee, Dhaka (pp. 87-200).

Halim, M. A. (2010b). Making the Constitution of Bangladesh. In Draft of the Original Constitution of 1972, Dhaka (pp. 59-86).

Khondker, R. (2013). Empowering women through reserved seats in the parliament: Fight or flight response? Dhaka, Bangladesh: Abdul Momen Khan Memorial Foundation.

Krook, M. L. (2006). Gender quotas, norms and politics. Politics \& Gender, 2(1), 110-128.

Majumdar, B. A. (2010). Women's participation in parliament: An alternative proposal in local governance and political reform. Dhaka, Bangladesh: Agamee Prakashani.

Mantoo, S. A. (2014). Religion and politics in South Asia. Peace and Security Review, 6(13).

Nanivadekar, M. (2006). Are quotas a good idea? The Indian experience with reserved seats for women. Politics \& Gender, 2(1), 119-128. doi:10.1017/S1743923X06241011

Pires, M. (2002). East Timor and the debate on quotas. Paper presented at the International IDEA Workshop: The Implementation of Quotas: Asian Experiences. Jakarta, Indonesia.

Sibalukhulu, N. (April 20, 2012). SA's electoral system fails the people. Mail and Guardian. Retrieved from https://mg.co.za/article/2012-04-20-sas-electoral-system-fails-the-people

The International Foundation for Electoral Systems (IFES). (12 July 2016). Report on gender equality, titled "Women's reserved seats in Bangladesh: A systemic analysis of meaningful representation". Retrieved from https://www.ifes.org/sites/default/files/2016_ifes_womens_reserved_seats_in_bangladesh_a_systemic_analysis_of_meaningf ul_representation.pdf

Varghese, R. M. (2015). Gender quotas - A catalyst for political empowerment of women. International Journal of Advanced Research, 3, 179-184. Retrieved from http://www.journalijar.com/uploads/774_IJAR-5137.pdf 